Бактыгуль Матисаева

Беркутбек Дарбанов

\section{Структурно-семантический анализ пословиц по сходству образного значения и внутренней формы}

В статье проведен структурно-семантический анализ кыргызских и русских пословиц, связанных с отношением человека к его внешнему и внутреннему миру. Авторы пытаются классифицировать соответствующие паремии на разные темы и провести сопоставительный семантический анализ. В лингвистических исследованиях был определен круг значений, который вошел в этот фрагмент семантического поля, а именно «внешность обманчива» и «лицо - отражение внутреннего мира». Цель статьи - показать сходство и различие кыргызских и русских пословиц путем сопоставления их фразеологического значения, внутренней формы и экспрессивнооценочных коннотаций. Сопоставительный анализ внутренней формы и образного значения, анализ структуры текста пословиц и их лексических компонентов показал, что в обоих языках присутствуют одни и те же тематические группы, качественный состав которых практически совпадает. Лексическое значение, коннотация и семантика паремий обнаруживают значительные сходства, при наличии некоторых исключений.

Ключевые слова: внутренняя и внешняя форма, денотат, коннотация, образное зна чение, пословица, структурно-семантический анализ, фразеологическое значение, эмотивность, кыргызские пословицы

Пословицы - это поэтические миниатюры, воплощающие мудрость, вековой опыт и менталитет народа. Экспрессивная окрашенность и самобытность пословиц выражается через образность значения и внутреннюю форму. Созданию образности способствуют параллелизм синтаксических конструкций, противопоставление и сопоставление, контрастность. По пословицам можно судить об особенностях национального характера, общности и различиях разных народов. Достаточно интересным представляется проведение сопоставительного анализа кыргызских и русских паремий, связанных с отношением человека к его внутреннему миру и внешности.

\section{Матисаева}

Бактыгуль Араповна,

старший преподаватель кафедры мировых языков Ошского гуманитарно-

педагогического института (Ош, Кыргызстан), mbaktygularapovna@gmail.com

\section{Дарбанов}

Беркутбек Ерматович

доктор филологических наук, профессор кафедры межкультурной коммуникации и лингвистики Джалал-Абадского государственного универси-

тета (Джалал-Абад,

Кыргызстан), darbanovb@mail.ru
Культурное своеобразие и национальная специфика мышления русского и кыргызского народов выражается че рез анализ лексических компонентов синтаксической структуры, ритмической организации кыргызских и русских пословиц, в которых специфическую роль играют языковые средства В сопоставлении паремий различных этносов в первую очередь обращается внимание на характерные особенности значения и внутренней формы пословиц, на их ритмические, фонетические и структурные особенности, парадигматические связи, способ манифестации значения, своеобразие семантики лексических компонентов, входящих в структуру пословиц.

Лингвисты используют термины «внутренняя форма», «образное значение» в структурно-семантическом анализе пословиц сопоставляемых языков. «Внутренняя форма» подразумевает буквальное значение пословицы, состоящее из значений его элементов. Это может быть как с буквальным значением, так и с переносным. Это значение включает как собственно значение (денотат), так и оценочность, эмотивность (имманентное свойство языка выражать психологические состояния и переживания человека), әкспрессию (дополнительную коннотацию) и является фразеологическим или паремиологическим значением. Сравнитель- 
ное исследование «пословичной картины мира позволяет установить общие и различные черты в постижении мира разными народами» $[3$, с. 5].

Сравнительный семантико-структурный анализ русских и кыргызских паремий, выражающих соотношение внутреннего и внешнего содержания личности, показал, что семантико-фразеологическое пространство связано с концептом «характер человека». Неповторимое значение этого концепта обусловлено множеством факторов: геополитических, климатических, исторических и прочих; он аккумулирует в себе дух и культуру этноса и во многом способствует формированию культурнолингвистических констант. Человек в языковой картине мира производит три разных вида действий: физические, интеллектуальные и речевые [1, с. 39]. Эти действия взаимосвязаны и влияют на формирование человеческого характера. Сопоставим кыргызские и русские паремии, определяющие шкалу человеческих ценностей.

Мы провели исследование лексических компонентов, структуры текста паремий (пословиц), а сопоставительный анализ их образного значения и внутренней формы помог определить схожесть и различия паремиологических значений кыргызского и русского языков. В данном семантическом пространстве пословицы рассматривались с двух позиций:

- внешность обманчива;

- внешность не всегда передает духовнъе свойства личности,

- суть человека определяют его поступки, а не внешние данные,

- внешная красота изменчива,

- у каждого свой эталон красоть,

и, наоборот:

- достоинства человека иногда можно определить по его внешнему виду,
- некрасивая внешность часто скрывает красивую душу,

- личо - отражение внутреннего мира.

С данных позиций сопоставление кыргызских и русских паремий позволило разделить их на кластеры по схожести внутреннего содержания и образного значения. Пословицы со значением «о человеке нельзя судить по первому впечатлению или по его внешности» и «внешность обманчива» оказались самыми многочисленными.

Прежде всего рассмотрим пословицы «универсальной языковой ментальности» [2, с. 7], содержащие совпадающий набор образов. К примеру, совпадают образы в русской «Не все то золото, что блестит» и кыргызской пословицах «Тышы жылтырак, ичи кылтыраак» (букв. «Снаружи блестящее, а внутри дрожащее»). Обе пословицы имеют экспрессивное образное значение, которое выражается в метафорическом переосмыслении лексического составляющего «золото» в значении «внешность обманчива».

Противоположная по смыслу пословица «Золото и в грязи блестит» также имеет кыргызский аналог «Алтын отто билинет, адам эмгекте билинет» (букв. «Золото познается в огне, человек в деле»). В этих паремиях с общим концептуальным ядром происходит необычное образное переосмысление. В кыргызской пословице подчеркивается важность репутации, она более конкретна. Обобщенная форма русской паремии нивелируется благодаря прозрачной внутренней форме. В итоге пословица становится понятной носителям разных языков и культур.

Средством выражения оценочности и эмотивности паремий служат неординарные лексические составляющие и их комбинации. Приоритет внутреннего содержания человека по отношению к внешности выражен в следующих кыргызских пословицах: «Сулулуктан жъ- 
луулук артык» (букв. «Теплота дороже красотъ»), «Жузун эмес ичин таза болсун» (букв. «Пусть лучше душа будет ии стой, чем лищо»), в которых делается акцент на семантическую антитезу. В этих паремиях оценочность проявляется в антонимичности лексических составляющих и правильном подборе лексики, в них прямое значение совпадает с переносным. Метонимическое переосмысление соматизмов прослеживается во второй паремии.

Такое же значение имеют следующие русские пословицы: «Глаза - бирюза, а душа - сажа», «Молодеи красив, дана душукрив», «Борода велика, а ума ни налька», «Рубашка бела, да душа черна», «Снаружи мило, внутри гнило», «Родилась пригожа, да по нраву негожа», “Личом хорош, да душой не пригож», «Со лба красив, да с затьлка вшив», «С виду гладко, да на зуб не сладко», «Лииом детина, да разумом скотина».

Как видим, русские пословицы строятся на противопоставлении лексических компонентов, находящихся в антонимических отношениях. Они носят фольклорный характер, ритмически организованы, содержат разговорную поэтическую лексику (пригожа, негожа, детина) и придают бо́льшую выразительность, экспрессию и оценочность речи. Яркая образность, экспрессия присуща и кыргызским паремиям: «Келбети келгенден кееш сура» (букв. «Совета спрашивай у того, кто выглядит симпатичным»), «Адам аласы - ичиенде, мал аласы тышында» (букв. «Пятна у скотины снаружи, а у человека - изнутри»). В основе фразеологического образа последней пословицы лежит зооним. В русском языке имеются аналогичные пословицы: «Пестрава красава, да буренка с молочком», «Гладка шерстка, да коготок остер», «Черная корова, да белое молочко». Они в равной степени экспрессивны и их внутренняя форма совпадает.

К этой же группе примыкают пословицы, которые привносят дополнительное значение - «первое впечатление обманчиво».
Например, в русском языке:

- По одежке встречают, по уму провожают.

- Не всяк умен, кто в красно наряжен.

- Личико беленъко, да ума маленъко.

- Дух бодр, да плоть немошна.

- Собой-то краля, а умом-то фаля.

- Ростом с Ивана, а умом с болвана.

В кыргызском языке:

- Бир коргондо - тон сыйлуу, таанышканда - бой сыйлуу. (букв. На первый взгляд - иуба дорога, познакомишься - рост дороже);

- Жаман кийимдин ичинде жальндаган журок бар (букв. Под бедной одеждой - пламенное сердие).

В данных пословицах отражается менталитет человека, в них внимание акцентируется на противоречии внутреннего содержания и внешней формы. Разговорность им придается за счет употребления просторечной лексики, синтаксических параллелизмов и рифмы.

К данной тематике так же относятся пословицы, имеющие еще одно дополнительное значение - «о человеке судят не по красоте, а по его поступкам»:

- Не по виду суди, а по делам глади.

- Не тот хорош, кто личом пригож, а тот хорои, кто для дела гож.

С отрицательным значением:

- Личиком гладок, да делами гадок.

- Хороша очами, да не хороша речами.

- Собой красава, да не по красаве слава.

- Глаз с поволокой, роток с позевотой.

- По бороде хоть в рай, а по делам - ай-ай!

- По бороде Авраам, а по делам Хам.

С положительным значением:

- Платье черненько, да совесть беленъка.

- Плоха рожа, да душа гожа.

- Глазами и кос, да душою прям. 
- Криво дерево, да яблоки сладки.

- Неказист личом, да трахнет молодиом.

- И толст, да прост, и не телен, да делен.

В кыргызском языке:

- Бойго чак кийим табу оной, ойго чак киши табу кыйын (букв. Легче найти одежду по росту, чем человека по душе).

- Онун суук болсо да, созун жылуу болсун (букв. Пусть будут приятными слова, даже если внешность неприглядна).

- Сулуукту козунон издебее, ишинен изде (букв. Красоту иши не в глазах, а в делах).

Немало пословиц в кыргызском и русском языках в значении: «красота там, где есть любовь», «каждый красоту понимает по-своему». В русском языке:

- Слица воду не пить.

- Милее всего кто любит кого.

- Не красивая красива, а любимая.

- Не то мило, ито хорошо, а то хорошо, ито мило.

- Не по хорошему мил, а по милу хорош.

- Милому мила - и без белил бела.

В кыргызском языке:

- Сулуу сулуу эмес, суйгон сулуу (букв. Красив не красивый, а влюбленный).

- Сулуунун корку козундо, чечедин корку - созундо (букв. У красавичы красота в глазах, красота красноречивого в словах).

- «Абийирдуу аялын - сулуун ошо!» (букв. Порядочная жена - твоя красота)

- «Ажардуу аял - адамдын периштеси, акылдуу аял эркектин шериктеши» (букв. Красивая женшина - ангел для человека, умная женшина - соратнича мужиинъ).

- «Сулуу жузду коргондо конул жанат» (букв. Когда видишь красивое личо, душа радуется).

- «Сулуу аял козунду тойгузат, акылдуу аял мээнди толтурат» (букв. Красивая женшина насышает глаза, умная женшина наполняет мозг).
В ходе структурно-семантического анализа была выявлена идентичность многих паремий (пословиц) русского и кыргызского языков, связанных с отношением человека к его внешнему и внутреннему миру: в обоих языках присутствуют одни и те же тематические группы, качественный состав которых практически совпадает. Лексическое значение, коннотация и семантика паремий обнаруживают значительное сходство, при наличии некоторых исключений. Кыргызские и русские пословицы данного семантического фрагмента не только отражают взаимосвязь внешности человека с его внутренним миром в менталитете русского и кыргызского народов, но и дополняют, расширяют и детализируют пословичную картину мира.

\section{Лumepamypa:}

1. Апресян Ю.Д. Образ человека по данным языка: попытка системного описания // Вопросы языкознания. 1995. № 1. С. 37-67.

2. Дубровская О.Г. Русские и английские пословицы как культурологические единицы // Вестник РуДН. Серия «Теория языка. Семиотика. Семантика». 2013. № 3. C. $60-69$.

3. Жуков В.П. Словарь русских пословиц и поговорок. М., 1990. 535 с.

\section{Baktygul Matisaeva,}

Senior instructor of the Department of world languages, Osh Pedagogical Institute of Humanities (Osh, Kyrgyzstan), mbaktygularapovna@gmail.com

\section{Berkytbek Darbanov,}

Doctor of Philology, Professor of the Chair «Intercultural communication and linguistics», Jalal-Abad State University (Jalal-Abad, Kyrgyzstan),

darbanovb@mail.ru

\section{Structural and semantic analysis of proverbs on similarity of figurative meaning and internal form}

This article deals with the structural-semantic analysis of Kyrgyz and Russian proverbs related to a person's attitude to his outer and inner world. An attempt was made to classify 
the corresponding paremias into various thematic groups and to conduct a comparative semantic analysis. In linguistic research a circle of meanings was defined that insert this fragment of the semantic field, exactly «appearance is deceiving» and «face is a reflection of the inner world». The aim of the article is to show the similarity and difference of Kyrgyz and Russian proverbs by comparing their phraseological meanings of internal forms and expressive-evaluative connotations. In the proverbs, the literal meaning coincides with the figurative, and evaluative is the selection of vocabulary and the antonym of the lexical components.

Keywords: internal and external form, denotation, connotation, figurative meaning, proverb, structural-semantic analysis, phraseological meaning, emotiveness

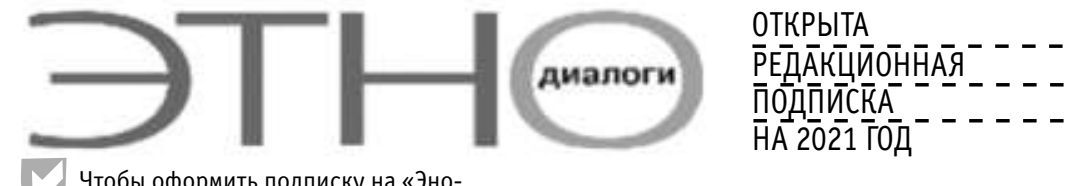

Чтобы оформить подписку на «Эно-

, - - -диалоги», вам нужно: - - -

1 - Оплатить стоимость подписки в банке или

оформить почтовый перевод на указанный

расчетный счет. Для удобства оплаты

I используйте опубликованную квитанцию

- Отправить квитанцию (копию) об оплате

или переводе по адресу: 119261, г. Москва,

ул. Панферова, д. 12. Центр межнацио-

нального образования «Этн
факсу +7 (499)134-50-98.

1 На обороте квитанции укажите,

пожалуйста, следующие даннье

Cipata:

Страна:

Город:

Улица:

Дом:

Корпус:

Квартира:

Ф.И.о. подписчика:

E-mail:

Почтовый индекс:

Альманах будет доставляться в ваш почтовый ящик!

Стоимость заказа 1 альманаха -125 рублей, 4 номера в год -500 рублей.

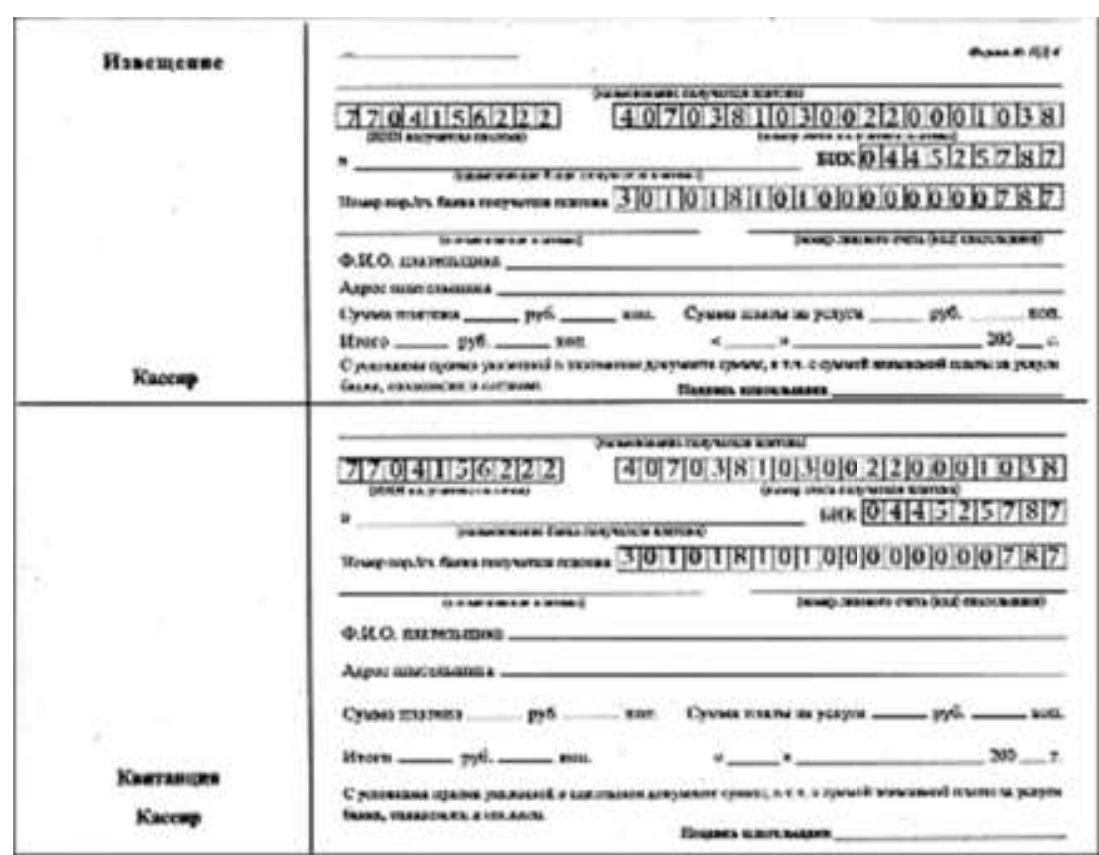

